\title{
Transformed major element based multidimensional classifi- cation of altered volcanic rocks
}

\author{
${ }^{1}$ Instituto de Energías Renovables, Universidad Nacional Autónoma de México, Temixco, Mor. 62580, Mexico; *Corresponding author, \\ E-mail:spv@ier.unam.mx \\ ${ }^{2}$ Posgrado en Ingeniería, Instituto de Energías Renovables, Universidad Nacional Autónoma de México, Temixco, Mor. 62580, Mexico, \\ E-mail:marig@ier.unam.mx
}

(Received: October 11, 2016; Revised accepted: May 26, 2017)

http://dx.doi.org/10.18814/epiiugs/2017/v40i4/017030

To fill the gap of the nomenclature of altered igneous rocks, a new exhaustive multidimensional classification scheme consistent with the International Union of Geological Sciences (IUGS) is proposed. Our procedure is based on an extensive database of major element compositions of a total of 32948 relatively fresh rock samples. The database consisted of multinormally distributed samples in terms of their 9 isometric log-ratios. The set of 48 new diagrams along with 76 discriminant functions provided acceptable success rates for most of the 17 root-names and 10 additional sub-root names. A new computer program IgRoClaMSys_ilr was written to facilitate an efficient use of our proposal. Good functioning of our multidimensional procedure was ascertained from 4 test studies of relatively fresh rocks, whereas 5 application studies of altered igneous rocks showed, as expected, greater discrepancy between the new and the IUGS schemes. Another important and novel application of this scheme for inferring the rock type of igneous provenance of siliciclastic sediments was demonstrated through 3 further application studies. IgRoClaMSys_ilr is also equipped with modules for ascertaining robustness of the new scheme with respect to analytical errors and post-emplacement compositional changes, including those related to hydrothermal alteration and low-grade metamorphism.

\section{Introduction}

According to the International Union of Geological Sciences (IUGS), the volcanic rocks can be classified from the well-known TAS (total alkalis versus silica) diagram after the separation of high-Mg rocks (Le Bas et al., 1986; Middlemost, 1994; Le Bas, 2000; Le Maitre et al., 2002). It is also clear that the TAS scheme proposed for 17 root names and 10 more sub-root names (Le Bas et al., 1986) should not be used for the classification of altered rocks. Le Bas et al. (1986) made the following points clear in their IUGS proposal (only some salient features are reproduced): (i) "The classification is purely descriptive" and "no genetic relationships are implied"; (ii) "It was designed for unaltered volcanic rocks", however, Middlemost (1994) has proposed a similar scheme for plutonic rocks; and (iii) "Analyses with $\mathrm{H}_{2} \mathrm{O}^{+}>2$ weight per cent or with $\mathrm{CO}_{2}>0.5$ per cent should be regarded with suspicion. All analyses must be recalculated to 100 per cent and free of $\mathrm{H}_{2} \mathrm{O}$ and $\mathrm{CO}_{2}$ ".

The IUGS classification will not be suitable for metamorphic rocks involving post-emplacement chemical changes. For altered rocks, the IUGS did not recommend any classification procedure (Le Bas et al., 1986; Le Maitre et al., 2002). The available schemes, such as Floyd and Winchester $(1975,1978)$ Winchester and Floyd (1976, 1977), have been shown unsuitable for this purpose (Verma et al., 2010).

The chemical compositions of altered rocks can be considerably modified from their initial concentrations. This includes $\mathrm{SiO}_{2}$ and total alkalis $\left(\mathrm{Na}_{2} \mathrm{O}\right.$ and $\left.\mathrm{K}_{2} \mathrm{O}\right)$ as well. Besides, the compositional data per se are characterized by a constant sum and closure problem (e.g., Chayes, 1960; 1978; Butler, 1979, 1982) and certain statistically coherent solutions are required (e.g., Aitchison, 1984, 1986, 1999; Egozcue et al., 2003; Verma, 2015). The constant sum also renders that concentrations of all elements, whether mobile or immobile, will change if the rock is altered after its emplacement (Verma, 2015; Verma et al., 2016a, 2017a).

The IUGS has recommended that the classification of plutonic rocks be achieved through mineralogical considerations (e.g., Streckeisen, 1966, 1967; Le Bas et al., 1986; Le Maitre et al., 2002). However, there are certain well documented problems with the use of ternary diagrams (Butler, 1979; Verma, 2012, 2015). Nevertheless, the use of chemical classification for plutonic rocks consistent with the TAS scheme was suggested by Middlemost (1994). Such a classification will be especially useful when precise modal compositions are not available, being the case of most modern geochemical studies. However, this classification scheme meant for fresh rocks will not be applicable to altered rocks.

We propose a statistically coherent solution to the problem of altered rock nomenclature in terms of all 17 root-names and 10 additional sub-root names for volcanic and plutonic rocks in the multidimensional space of all major element log-ratios. The new multidimensional

This article contains electronic supplementary material which is available at the journal website (http://www.episodes.org/). 
scheme is evaluated from fresh igneous rocks not included in the original database and its application to altered volcanic or plutonic rocks is suggested as an essential step towards an adequate classification. The postemplacement changes may be due to hydrothermal alteration or low-grade metamorphism. A novel application is also documented for deciphering the rock type of igneous provenance of siliciclastic sediments.

\section{Methods}

\section{Database}

A worldwide representative database of major element compositions of relatively fresh Neogene igneous rocks was established. A total of 32948 samples with their schematic locations in Figure 1 are summarized in Table S1 (see Supplementary data file available for downloading from the journal website, as well as from our website tlaloc.ier.unam.mx). The samples compiled from over 1000 papers were first classified from the IUGS scheme applied through the IgRoCS computer program (Verma and Rivera-Gómez, 2013). A synthesis of the complete database is available from http://tlaloc.ier.unam.mx/index. html.

For the proposal of the new scheme, major elements were adjusted to $100 \%$ on an anhydrous basis with total $\mathrm{Fe}$ as $\mathrm{Fe}_{2} \mathrm{O}_{3}{ }^{\mathrm{t}}$ from equations listed in Table S2. The conversion to $\mathrm{Fe}_{2} \mathrm{O}_{3}{ }^{\mathrm{t}}$ was achieved from the first equation in Table S2. This equation will be useful, irrespective of whether $\mathrm{Fe}$ was reported as $\mathrm{FeO}^{t}$ or as its two oxidation varieties $\mathrm{FeO}$ and $\mathrm{Fe}_{2} \mathrm{O}_{3}$. The use of $\mathrm{FeO}^{\mathrm{t}}$ instead of $\mathrm{Fe}_{2} \mathrm{O}_{3}{ }^{\mathrm{t}}$ for the proposal of our multivariate classification technique will not change the conclusions; only the coefficients of the discriminant function equations will change. The major element adjusted data were then transformed to isometric log-ratios from equations of Table S3. The conversion of $\mathrm{Fe}$ and later adjustment to $100 \%$ anhydrous, render the database more uniform and suitable for their log-ratio transformation.

\section{Log-ratio Transformation and Multinormality Tests}

Isometric log-ratio (ilr) transformation of Egozcue et al. (2003) was used. The other transformations (additive and centred log-ratios of Aitchison, 1986) would provide the same final results for any given database (Verma, 2015). The multinormality test (Wilks, 1963; Barnett and Lewis, 1994; Rencher, 2002) was applied through a new computer program DOMuDaF by Verma et al. (2016a), which has also been successfully used by Verma et al. (2017a) for inferring discordancy of multivariate outliers and proposing a new magma type classification scheme. Thus, only the multinormally distributed samples in terms of their 9 log-ratios were considered.

\section{Linear Discriminant and Canonical Analysis}

The multinormally distributed ilr data of 32948 samples were used for the application of the multivariate technique of linear discriminant analysis (LDA) and canonical analysis (Table S1; the individual transformed data are not shown here but will be available as Excel files from http://tlaloc.ier.unam.mx/index.html). The tests for equality of group means show that all 9 log-ratios (ilr1TiM to ilr9PM) have statistically significant differences among the four main classes or groups of magma types at a low significance level approaching 0.000000 (Table S4). All ratios can therefore be used for further analysis. Similarly significant differences were also observed for different rock types but are not reported here to keep the paper short.

The complete database of multinormally distributed isometric logratios of 32948 (1505 ultrabasic, 12204 basic, 11750 intermediate and 7489 acid; Table S1) rock samples was used for proposing a set of 48 new diagrams (only a few diagrams are shown in the Supplementary data file) and 76 discriminant functions (all equations are listed in the Supplementary data file). After carrying out LDA, probabilities for individual samples were calculated from the method outlined by

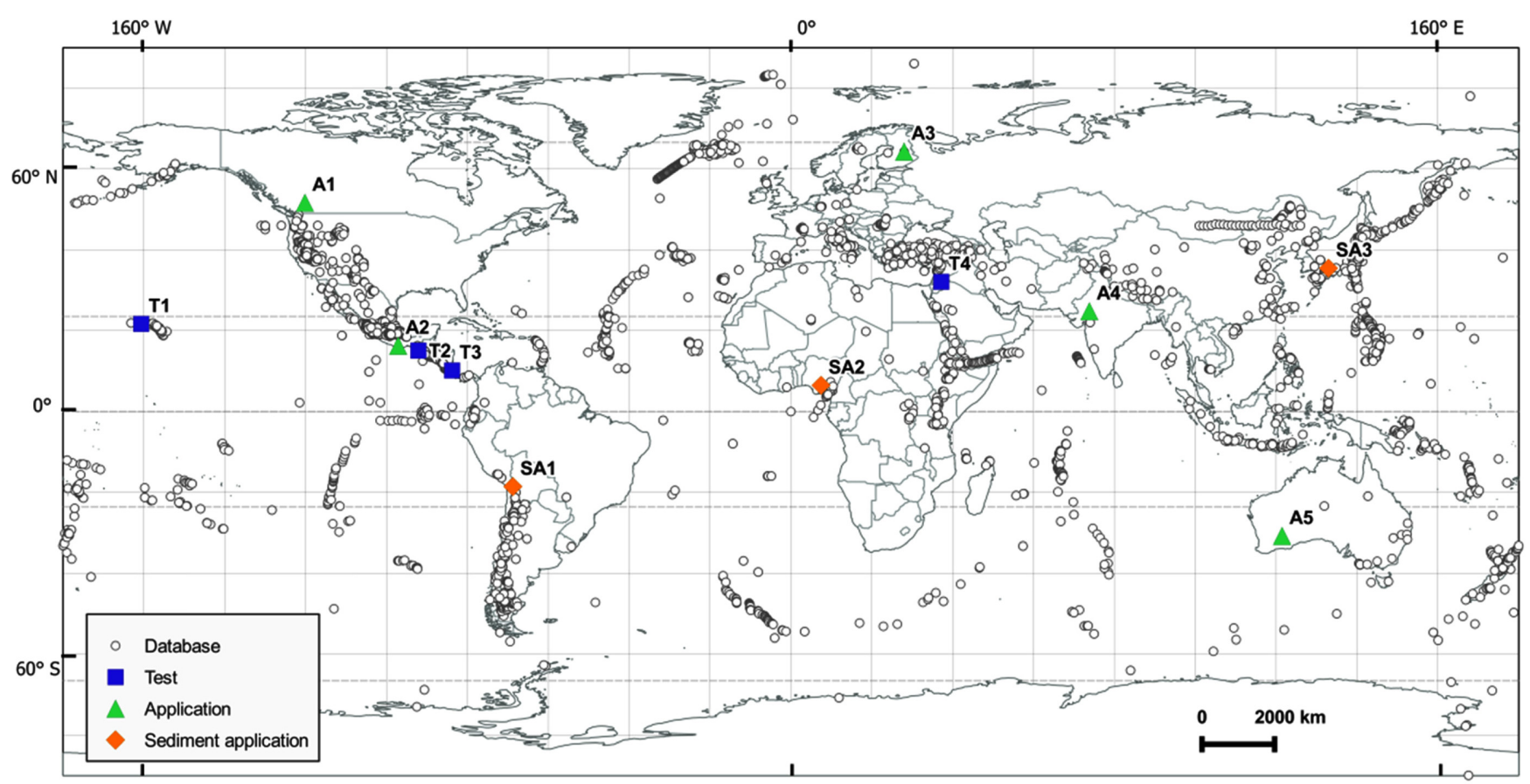

Figure 1. Map for schematic locations of samples used for constructing the database, including locations of tests and application studies. 
Agrawal (1999), Verma and Agrawal (2011) or Verma and Verma (2013). They were used in this work to decide the classification field in which a given sample will plot. For probability calculations, group centroids represented by the mean values were used, because this statistical parameter would provide the best estimate of the central tendency when appropriate discordancy tests are used for identifying and separating discordant outliers from the datasets (Verma et al., 2016b, 2017b).

\section{Computer Program for Classification for Altered Igne- ous Rocks}

For an efficient application of the new multidimensional scheme, a computer program IgRoClaMSys_ilr (Igneous Rock Classification
Major-element based System from isometric log-ratios) was written in Java Framework ZK (Fig. 2). Before using the program, the user must make sure that the rocks to be processed in IgRoClaMSys_ilr are not of high-Mg type (Le Bas, 2000). For such fresh rocks, the original criteria (Le Bas, 2000) can be used but, for altered rocks, it may be necessary to first use a published computer program HMgClaMSys_mlr (Verma et al., 2016a; usable at http://tlaloc.ier.unam.mx/index.html) in order to ascertain the high-Mg nature of altered rocks. If the rocks are classified as of high-Mg type, HMgClaMSys_mlr will provide their nomenclature (komatiite, meimechite, picrite, and boninite), consistent with the IUGS (Le Bas, 2000).

The first part of IgRoClaMSys_ilr concerns data validation and transformation (Tables S2 and S3). The information on whether one is

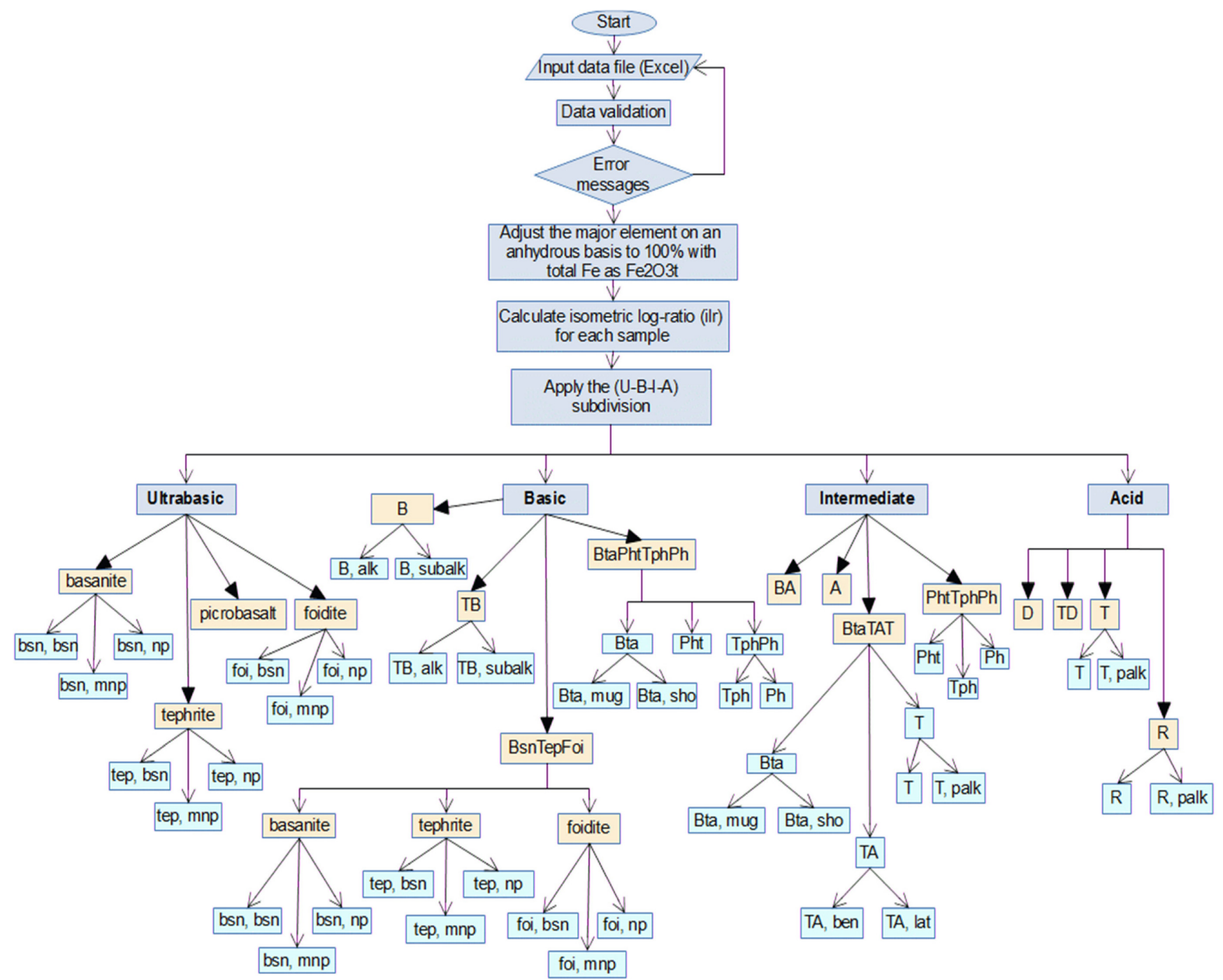

Figure 2. Schematic flow diagram of the new computer program IgRoClaMSys_ilr. The abbreviations used are as follows: $U$ - ultrabasic; $B$ basic; I-intermediate; $A$-acid; BSN-basanite; TEP-tephrite; PB-picrobasalt; FOI-foidite; BSN, bsn-basanite, basanite; BSN, mnpbasanite, melanephelinite; BSN, np - basanite, nephelinite; TEP, bsn - tephrite, basanite; TEP, mnp-tephrite, melanephelinite; TEP, np tephrite, nephelinite; FOI, bsn-foidite, basanite; FOI, mnp - foidite, melanephelinite; FOI, np-foidite, nephelinite; B - basalt; TB - trachybasalt; BsnTepFoi - group of basic basanite, tephrite, and foidite; BtaPhtTphPh-group of basaltic trachyandesite, phonotephrite, tephriphonolite, and phonolite; B, alk - basalt, alkali; B, subalk - basalt, subalkali; TB, haw - trachybasalt, hawaiite; TB, pot - trachybasalt, potassic; BA - basaltic andesite; A - andesite; BtaTAT - group of basaltic trachyandesite, trachyandesite, and trachyte; BtaPhtTphPh group of basaltic trachyandesite, phonotephrite, tephriphonolite, and phonolite; Bta, mug - basaltic trachyandesite, mugearite; Bta, sho basaltic trachyandesite, shoshonite; TA, ben - trachyandesite, benmorite; TA, lat-trachyandesite, latite; T, palk-trachyte, peralkaline; Ddacite; TD-trachydacite; $T$-trachyte; $R$-rhyolite; $T$, palk-trachyte, peralkaline; $R$ palk-rhyolite, peralkaline. 
dealing with volcanic or plutonic rocks is to be provided. Consequently, IgRoClaMSys_ilr decides the appropriate way to process the data. Calculations involve the probability values for all competing rock types corresponding to different diagram sets. Plotting of samples in diagrams is not at all needed. The rock is given the name for which the probability is highest (Fig. 2). IgRoClaMSys_ilr reports the results as two different Excel output files (a brief or an extensive report at user's choice; as the default option, only brief report is generated). This program will be available at http://tlaloc.ier.unam.mx/index.html to interested users for online processing of their major element data.

The modules in IgRoClaMSys_ilr include the following: (a) Conventional application to older or altered igneous rocks as well as the inference for igneous rock type provenance of siliciclastic sediments; (b) Robustness against analytical errors or uncertainties; and (c) Robustness of the new classification for post-emplacement alteration changes likely caused by hydrothermal or low-grade metamorphic processes.

\section{Results}

\section{New Multidimensional Scheme}

The complete database was subdivided into four magma types, for which 10 multidimensional discriminant functions (Eqs. S1 to S10 in Table S5) in 5 DF1-DF2 type diagrams (Figs. S1a-e) were proposed. The probability-based boundary coordinates in these five diagrams are listed in Table S6. The percent success in these diagrams (Figs. S1a-e) varied from $79.3 \%$ to $99.3 \%$ (Table S7). One sample (ME9011; Binard et al., 1993) was used to illustrate the procedure. According to the IUGS scheme, this is an ultrabasic rock; the data are plotted in Figures S1a-e (filled diamond) and the respective probability values are summarized in Table S8. The final synthesis of percent probability (\%prob of 70.8\%; Table S8) from the new scheme clearly confirmed that this is an ultrabasic rock. Because a given field is always absent in any set of such diagrams (Figs. S1a-e), the final percent probability for any given field can never reach $100 \%$. The overall percent success (correct classification as a synthesis of all five diagrams; Figs. S1a-e) for the entire database varied from about $76.8 \%$ for basic to $92.3 \%$ for ultrabasic rocks (Table S9). This division was followed by 17 root and 10 sub-root names.

The ultrabasic rocks were subdivided by 10 discriminant functions (Eqs. S11 to S20 in Table S10) and 5 diagrams (Figs. S2a-e; probability-based boundaries in Table S11) as basanite, tephrite, picrobasalt and foidite. The percent success varied from about $76 \%$ to $92.1 \%$ (Table S12). The same sample ME90-11 (Binard et al., 1993; filled diamond symbol in Figs. S2a-e) was used to illustrate the probability concept in these diagrams, where the IUGS name basanite was confirmed from the new classification scheme (total probability value for this field 77\%; Table S13). The overall percent success (correct classification) varied from $78 \%$ for picrobasalt to about $89 \%$ for ultrabasic tephrite (Table S14).

These ultrabasic rocks were further subdivided for their sub-root names. Basanite as basanite, melanephelinite and nephelinite varieties (2 discriminant function Eqs. S21 and S22 in Table S15; Fig. S3a); picrite as basanite, melanephelinite and nephelinite varieties (2 discriminant function Eqs. S23 and S24 in Table S16; Fig. S3b); and foidite also as basanite, melanephelinite and nephelinite varieties (2 discriminant function Eqs. S25 and S26 in Table S17; Fig. S3c). Probabilitybased boundaries in Figures S3a-c, are provided in Table S18. The percent success varied from about $84 \%$ to $98 \%$, with the exception of foidite, basanite represented by only 7 samples (Table S19). The ultrabasic basanite, basanite sample ME90-11 (IUGS classification) used for illustration (Fig. S3a) proved to have the same name from the present scheme (percent probability of about 0.8123 for the basanite subfield (Table S20).

The basic rocks were first subdivided as basalt (B), trachybasalt (TB), group of basanite, tephrite and foidite (BsnTepFoi), and group of basaltic trachyandesite, phonotephrite, tephriphonolite and phonolite (BtaPhtTphPh). The discriminant function Equations (S27) to (S36) are listed in Table S21. It is really not necessary to construct diagrams and plot samples therein. Nevertheless, we provide the boundary coordinates (Table S22) in case someone wants to actually plot the samples and construct diagrams. Table S23 gives the percent success values for each of the five diagrams and Table S24 lists the overall success for this four-fold division of basic rocks.

Basalt can be subdivided into its two varieties (alkali and subalkali basalts) from the discriminant function (Eq. S37 in Table S25). The percent success for this rock type was high $(95.7 \%$ for alkali basalt and $91.4 \%$ for subalkali basalt; Table S26). Similarly, trachybasalt was subdivided as hawaiite and potassic varieties (discriminant function Eq. S38; Table S27). The success values for this subdivision were also high $(94.2 \%$ for hawaiite and $86.9 \%$ for potassic variety or sub-root name; Table S28).

The group BsnTepFoi was separated into three rock types (basanite, tephrite, and foidite) from the discriminant function Equations (S39) and (S40) (Table S29). The probability-based boundary coordinates are listed in Table S30. The percent success values for this three-fold division varied from $84.3 \%$ to $95.1 \%$ (Table S31). Using Equations (S41) and (S42) (Table S32), the basanite was further subdivided three subvarieties (basanite, melanephelinite, and nephelinite). Similarly, tephrite was subdivided into the same three subvarieties from Equations (S43) and (S44) (Table S33) and foidite into two subvarieties (melanephelinite and nephelinite) from Equation (S45) (Table S34). The boundary coordinates for the basanite and tephrite subdivision are listed in Table S35. The percent success values ranged from $87.3-93 \%$ for basanite, $84-91 \%$ for tephrite, and $100 \%$ for foidite (Table S36).

The group BtaPhtTphPh was also divided into three rock types (basaltic trachyandesite, phonotephrite, and combined tephriphonolite and phonolite) from Equations (S46) and (S47) (Table S37). The field boundaries are listed in Table S38. The percent success values varied from about $83 \%$ to $93.6 \%$ (Table S39). Basaltic trachyandesite was subdivided as two subvarieties (mugearite and shoshonite) from Equation S48 (Table S40) with percent success of $96.4 \%$ and $88.9 \%$, respectively (Table S41). The two rock types (tephriphonolite and phonolite) were divided into these two varieties from Equation (S49) (Table S42) with success values of $100 \%$ (Table S43).

The intermediate rocks were first divided as basaltic andesite (BA), andesite (A), group of basaltic trachyandesite, trachyandesite and trachyte (BtaTAT), and group of phonotephrite, tephriphonolite and phonolite (PhtTphPh). The relevant discriminant function Equations (S50) to (S59) and field boundaries are given in Tables S44 and S45, respectively. Table S46 provides the percent success values that vary from 
$83.5 \%$ to $95.6 \%$, whereas Table S47 reports the overall success rates for the classification of the intermediate rocks as four rock groups which varied from $80.8 \%$ for the group of BtaTAT to $91.5 \%$ for basaltic andesite.

The intermediate rock group BtaTAT was further divided into the three rock types (basaltic trachyandesite, trachyandesite, and trachyte) from discriminant function Equations (S60) and (S61) (Table S48; boundary coordinates in Table S49) with percent success values of $85.5 \%$ to 94.8\% (Table S50). The basaltic trachyandesite rocks were further subdivided for sub-root rock names of mugearite and shoshonite from Equation (S62) (Table S51), with percent success values of 98.5\% and $82.9 \%$, respectively (Table S52). Trachyandesite rocks were similarly subdivided as its two sub-root rock names of benmorite and latite (Eq. S63; Table S53) with percent success values of $97.3 \%$ and $78.9 \%$, respectively (Table S54). The intermediate trachyte rocks were subdivided as trachyte and peralkaline trachyte from discriminant function Equation (S64) (Table S55) and percent success values of $96.2 \%$ and $90 \%$ were obtained for this subdivision (Table S56).

The intermediate rock group $\mathrm{PhtTphPh}$ was divided into three rock types phonotephrite (Pht), tephriphonolite (Tph), and phonolite $(\mathrm{Ph})$ from Equations (S65) and (S66) (Table S57; boundary coordinates in Table S58) with percent success values listed in Table S59.

Finally, the acid rocks were first divided in five diagram set as dacite, trachydacite, trachyte, and rhyolite (Eqs. S67 to S76; Table S60; boundary coordinates in Table S61). The percent success values for individual diagrams varied from $72.9 \%$ to $98.5 \%$ (Table S62), whereas the overall success values ranged from $77.6 \%$ for trachyte to $86.9 \%$ for dacite (Table S63).

The acid trachyte rocks were subdivided as two sub-root names (trachyte and peralkaline trachyte) from Equation (S77) (Table S64) and percent success values of $95.9 \%$ and $88.9 \%$ were obtained (Table S65). Finally, rhyolites were subdivided as rhyolite and peralkaline rhyolite from Equation (S78) (Table S66) obtaining success values of $99.4 \%$ and $95.9 \%$, respectively (Table S67).

\section{Discussion}

This section is subdivided into four subsections: (1) Overall success of the alternative IgRoClaMSys_ilr scheme for assigning root and sub-root names for the complete database evaluated in the light of the IUGS scheme as a reference; (2) Success of the new scheme for individual test studies of fresh rocks also evaluated against the IUGS scheme; (3) Application of IgRoClaMSys_ilr to altered igneous rocks evaluated against the original IUGS scheme proposed for fresh rocks only; (4) Additional application studies for igneous provenance of siliciclastic sediments; and (5) Mention of the additional modules of IgRoClaMSys_ilr for ascertaining the robustness of the new scheme with respect to analytical errors and post-emplacement compositional changes.

\section{Overall Success for the Alternative IgRoClaMSys_ilr Scheme}

The complete database (32948 analyses) was first processed to evaluate the correctness or percent success of the classification of 17 root names (Table 1) and all 29 root and sub-root names (Table S68). The IUGS scheme (Le Bas et al., 1986) was used as reference. For 12 root names, the percent success was relatively high $62.4 \%$ for tephriphonolite to $86.7 \%$ for rhyolite (Table 1). For the remaining 5 root names, it was lower, although for only two cases (picrobasalt and phonotephrite), it could be considered unacceptably low (Table 1). Similarly, for 29 root and sub-root names of Le Bas et al. (1986) percent success values of $>50 \%$ were obtained for 22 rock types, with the remaining rock types showing lower values (Table S68). Nevertheless, these percent success values are significantly higher than those obtained for the available alternative diagrams of Floyd and Winchester $(1975,1978)$ Winchester and Floyd $(1976,1977)$ as demonstrated by Verma et al. (2010).

\section{Testing of the New Rock Classification Scheme from Fresh Rocks}

This IgRoClaMSys_ilr scheme was then applied for testing from relatively fresh rock data not included in the initial database (Tests T1 to T4 in Fig. 1).

For the first test (T1; Fig. 1; Table S69), the data for 62 Quaternary volcanic rock samples of Kaula volcanics, Hawaiian Islands (Garcia et al., 2016) indicated from the IUGS classification that 14 rocks were ultrabasic (3 basanite, basanite; 4 basanite, melanephelinite; 4 foidite, melanephelinite; 1 foidite, nephelinite; and 2 picrobasalt) and 48 basic (40 basalt, alkali; 1 basalt, subalkali; 6 basanite, basanite; and 1 trachybasalt, hawaiite). In terms of magma types, the IgRoClaMSys_ilr scheme provided 10 ultrabasic and 52 basic rocks, thus misclassifying only 4 ultrabasic as basic rocks. Thus, 58 out of 62 magma types as correctly classified amounted to about $94 \%$ correct classification. Now, in terms of rock types, the IgRoClaMSys_ilr correctly classified 40 samples of alkali basalt; 1 subalkali basalt; 1 basanite, basanite; and 4 basanite, melanephelinite (Table S69) amounting to about $74 \%$ correct classification. The incorrect classification was mainly the "neighbour" rock types, not drastically different from the original IUGS rock types (Table S69) because 8 basanite, basanite were classified as alkali basalt; 1 foidite, nephelinite as basanite, basanite; 4 foidite, melanephelinite as basanite, melanephelinite; 2 picrobasalt as alkali basalt; and 1 trachybasalt, hawaiite as alkali basalt.

The next test (T2; Fig. 1; Table S70) was from Holocene volcanic rocks of San Antonio volcano, Tacaná volcanic complex, Mexico-Guatemala (Mora et al., 2004). Out of 14 rock samples (IUGS: 12 intermediate and 2 acid rocks), 13 were correctly classified in terms of magma types (IgRoClaMSys_ilr: 11 intermediate and 3 acid rocks). In terms of rock types, 3 basaltic andesite, 8 andesite, and 1 rhyolite were correctly classified, with only 2 rocks ( 1 andesite and 1 rhyolite) incorrect as dacitic rocks.

Test T3 (Fig. 1; Table S71; Di Piazza et al., 2015) included 7 Quaternary volcanic rock samples of Turrialba volcano, Costa Rica. Out of 7 intermediate rocks, 6 proved to be as such, with the remaining classified as an acid rock, whereas, in terms of rock types, 5 (3 basaltic andesite and 2 andesite) were correctly classified (Table S71). One trachyandesite, benmorite was wrongly classified as andesite and 1 andesite as trachyte.

For Test T4 (Fig. 1; Table S72; Shaw et al., 2003), 32 MiocenePleistocene volcanic rock samples of Harrat Ash Shaam, Jordan were compiled. From the IUGS scheme, they were classified as 9 ultraba- 
Table 1. Classification of rock types (root names) from the initial database from the new multidimensional classification scheme and comparison with the IUGS classification scheme

\begin{tabular}{|c|c|c|c|c|c|c|c|c|c|c|c|c|c|c|c|c|c|c|c|c|}
\hline \multirow{2}{*}{$\begin{array}{c}\text { Rock } \\
\text { no. }\end{array}$} & \multirow{2}{*}{$\begin{array}{l}\text { Rock name } \\
\text { (IUGS) }\end{array}$} & \multirow{2}{*}{$\begin{array}{c}\text { No. of } \\
\text { samples } \\
\text { (IUGS) }\end{array}$} & \multicolumn{17}{|c|}{ Number of samples classified from IgRoClaMSys_ilr in any given field } & \multirow{2}{*}{$\begin{array}{l}\text { Percent suc- } \\
\text { cess (IgRoC- } \\
\text { laMSys_ilr) }\end{array}$} \\
\hline & & & 1 & 2 & 3 & 4 & 5 & 6 & 7 & 8 & 9 & 10 & 11 & 12 & 13 & 14 & 15 & 16 & 17 & \\
\hline 1 & basanite & 1484 & 1073 & 189 & 3 & 71 & & 65 & 20 & 63 & & & & & & & & & & 72.3 \\
\hline 2 & tephrite & 312 & 1 & 245 & 1 & 13 & & 6 & 1 & 44 & & 1 & & & & & & & & 78.5 \\
\hline 3 & picrobasalt & 72 & 7 & 5 & 21 & 39 & & & & & & & & & & & & & & 29 \\
\hline 4 & foidite & 268 & 12 & 25 & 2 & 186 & & & & 21 & & 22 & & & & & & & & 69.4 \\
\hline 5 & phonolite & 267 & & 1 & & & 236 & & & & & 24 & & & & 6 & & & & 88.4 \\
\hline 6 & basalt & 9349 & 616 & 271 & 26 & & & 6705 & 1317 & 49 & & & 365 & & & & & & & 71.7 \\
\hline 7 & trachybasalt & 1486 & 259 & 288 & & & & 6 & 667 & 245 & 3 & & 18 & & & & & & & 44.9 \\
\hline 8 & $\begin{array}{c}\text { basaltic } \\
\text { trachyandesite }\end{array}$ & 1678 & 3 & 76 & & & & 1 & 34 & 1359 & 13 & 4 & 113 & 8 & 67 & & & & & 81.0 \\
\hline 9 & phonotephrite & 341 & 7 & 94 & & & & & 3 & 140 & 49 & 41 & & & 7 & & & & & 14.4 \\
\hline 10 & tephriphonolite & 133 & & 13 & & & & & & 13 & 6 & 83 & & & 18 & & & & & 62.4 \\
\hline 11 & basaltic andesite & 3884 & 2 & 3 & & & & 540 & 254 & 502 & & & 2486 & 97 & & & & & & 64.0 \\
\hline 12 & andesite & 4136 & & & & & & & & 75 & & & 258 & 3653 & 150 & & & & & 88.3 \\
\hline 13 & trachyandesite & 1538 & & 4 & & & & & & 152 & 25 & 30 & 1 & 173 & 1142 & 5 & & 6 & & 74.3 \\
\hline 14 & trachyte & 1301 & & & & & 224 & & & & 18 & 38 & & 106 & 65 & 725 & 23 & 102 & & 55.7 \\
\hline 15 & dacite & 2750 & & & & & & & & & & & & 1134 & 8 & 8 & 1289 & 311 & & 46.9 \\
\hline 16 & trachydacite & 224 & & & & & & & & & & & & 8 & 1 & 42 & 3 & 170 & & 75.9 \\
\hline 17 & rhyolite & 3725 & & & & & & & & & & & & & & 93 & 117 & 286 & 3229 & 86.7 \\
\hline
\end{tabular}

sic ( 8 basanite, basanite; and 1 basanite, nephelinite) and 23 basic ( 17 basalt, alkali; and 6 basalt, subalkali) rocks. The IgRoClaMSys_ilr identified 6 samples as ultrabasic and 26 as basic, thus correctly classifying 29 samples for their magma types (Table S72), amounting to about $90 \%$ success. In terms of rock types, 29 samples (16 alkali basalt; 6 subalkali basalt; 6 basanite, basanite; and 1 basanite, nephelinite) were correctly classified by IgRoClaMSys_ilr. Only 2 basanite, basanite were misclassified as 2 alkali basalt and 1 alkali basalt as subalkali basalt (Table S72).

Thus, all four tests clearly show that the new scheme works well for the classification of fresh rocks.

\section{Application to Older Igneous Rocks}

For the new IgRoClaMSys_ilr scheme to be useful for the classification of older rocks, there should be more differences or inconsistencies with the IUGS scheme put forth for fresh rocks only. We present 4 application case studies (A1 to A4; Fig. 1) to illustrate the usefulness of IgRoClaMSys_ilr.

The first application is for the Paleoproterozoic Star Lake pluton, Canada (Application study A1; Fig. 1; Janser, 1992, 1994). Out of 78 analyses, 33 intermediate and 23 acid rocks from the IUGS scheme also proved to be as such from the IgRoClaMSys_ilr (Table S73). Nine basic and 13 acid rocks were classified as intermediate rocks by the new scheme, amounting to about $28 \%$ incorrect classification of magma types. The classification of rock types was even worse because only 38 samples (out of 78; Table S73) were correctly classified, amounting to only $49 \%$ correct classification. Because the studied rocks are plutonic, the equivalent plutonic rock names are provided in the last column (Table S73).

Our next application is for Paleozoic volcanic rocks of Juchatengo Complex, Mexico (Application study A2; Fig. 2; Table S74; GrajalesNishimura et al., 1999). Out of 13 samples classified as basic rocks from the IUGS scheme, 4 were classified as intermediate rocks from the IgRoClaMSys_ilr. Similarly, for their rock types, 5 out of 13 were differently classified by the IgRoClaMSys_ilr (Table S74).

Another application is concerned with Paleoproterozoic lava and sheeted dyke samples from Jormua ophiolite, Finland (Application study A3; Fig. 2; Table S75; Peltonen et al., 1996). Twenty-four out of 33 basic rock samples (according to the IUGS scheme) were classified as basic rocks, with the remaining 9 samples differently classified as ultrabasic ( 3 samples) and intermediate ( 6 samples). Similarly, only 21 out of 33 samples (amounting to about 64\%) were classified as the same rock types by both schemes (Table $\mathrm{S} 75$ ).

The next application is to Mesoproterozoic rocks of Delhi area, India (Application study A4; Fig. 2; Table S76; Abu-Hamatteh, 2000). From the IUGS scheme, 24 rock samples were classified as 1 ultrabasic, 13 basic, and 10 intermediate rocks, whereas from the IgRoClaMSys_ilr, the same rocks were subdivided as 2 ultrabasic, 20 basic, and 2 intermediate rocks. Similarly, The IUGS scheme determined these rocks as 1 picrobasalt, 2 alkali basalt, 11 subalkali basalt, 6 basaltic andesite, 2 basaltic trachyandesite (1 mugearite and 1 shoshonite), and 2 andesite. 
From the IgRoClaMSys_ilr scheme, 10 subalkali basalt and 1 basaltic andesite samples were classified as such, which represented only about $46 \%$ agreement between the two schemes. However, the two schemes provided different names for more (13) samples (Table S76), which once again suggests that the new scheme should be used for the nomenclature of altered rocks.

The final application to Archaean mafic magmatism in the Kalgoorlie area of the Yilgarn craton, Western Australia (Application study A5; Fig. 2; Table S77; Bateman et al., 2001). The IUGS scheme indicated that the magma types of 70 samples were distributed as follows: 2 ultrabasic, 31 basic, and 37 intermediate. The IgRoClaMSys_ilr scheme, on the other hand, classified them as 1 ultrabasic, 63 basic, and 6 intermediate rocks (Table S77). Only 30 basic and 5 intermediate rocks were consistently classified by both schemes (IUGS and IgRoClaMSys_ilr). The remaining 35 samples (amounting to 50\%) were classified differently (Table S77) for magma types. The two classification schemes differed even more for rock types because 41 samples out of 70 (amounting to 59\%) were classified differently (Table S77).

Because the good functioning of the new classification scheme was documented from the initial database as well as 4 independent tests, these significantly higher differences between the new and IUGS schemes for older rocks make it clear that the new scheme (IgRoClaMSys_ilr) should be used for the nomenclature of altered rocks.

We may also mention that the new classification scheme will be useful for hydrothermally or low-grade metamorphic or metasomatic rocks as suggested from their robustness against post-emplacement chemical changes (see the Section of "Robustness of the new multidimensional classification scheme" below). Therefore, the new procedure will be applicable in geothermal or mineral industries for the nomenclature of hydrothermally or metamorphosed or metasomatic igneous rocks.

\section{Application to Igneous Provenance of Siliciclastic Sedi- ments}

As an innovation, the new IgRoClaMSys_ilr scheme can be used for deciphering igneous provenance of sediments and sedimentary rocks. We illustrate this application from 3 studies (sediment application SA1 to SA3; data from Pinto et al., 2004; Odoma et al., 2015; and Ishiga et al., 2000, respectively). These applications contrast the provenance suggested by the original authors (Pinto et al., 2004; Odoma et al., 2015).

Pinto et al. (2004) presented sediment data from Bolivia and Chile (Fig. 2; adjusted major element chemical data in Table S78). Twelve samples from Bolivia indicated an acid and mainly rhyolitic provenance (12 acid rocks; 8 rhyolites, 3 trachydacite, and 1 dacite; Table S78). On the other hand, 26 Chilean samples were more consistent with an intermediate and andesitic provenance ( 21 intermediate and 5 acid rocks; 19 andesite, 3 dacite, 1 each basaltic andesite, trachyandesite, trachydacite and rhyolite; Table S78).

The second sediment application study (SA2; Fig. 2; Table S79) concerns sediments from Enugu, southeastern Nigeria (Sediment application study SA2; Odoma et al., 2015). The provenance is likely of basic rocks ( 6 out of 7 samples; Table S79). More specifically, it appears to be basaltic trachyandesite, mugearite (4 samples; 2 phonolite, and 1 rhyolite; Table S79), i.e., basic alkaline provenance.
The final application is for coastal lagoon sediments from southwest Japan (SA3; Fig. 2; Table S80; Ishiga et al., 2000). The sediment provenance can be inferred as from intermediate rocks (43 out of 49 rocks; about $88 \%$ ) and more specifically, basaltic andesite rocks (37 out of 49 rocks; about $76 \%$ ).

Thus, igneous provenance of sediments can be successfully inferred from the IgRoClaMSys_ilr.

\section{Robustness of the New Multidimensional Classification Scheme}

The additional modules programmed in IgRoClaMSys ilr enable the user to determine the robustness of their own samples (one at a time) with respect to analytical errors or uncertainties as well as postemplacement compositional changes such as weathering, hydrothermal alteration or low-grade metamorphic or metasomatic changes. The appropriate templates are included for an efficient use of these capabilities. The user is free to input data of an actual sample in the appropriate Excel file and watch the robustness of the multidimensional procedure.

\section{Conclusions}

The new multidimensional classification scheme proposed from linear discriminant and canonical analysis of 9 isometric log-transformed ratios of all major elements showed high percent success values (generally $>50 \%$ ) for most of the 17 root names and 10 sub-root names. New computer program IgRoClaMSys_ilr for online processing of data would facilitate its use by all those interested in correctly classifying old or altered igneous rocks as compared to the IUGS and other alternative procedures. This new scheme would be useful for the classification of weathered, hydrothermally altered or low-grade metamorphic or metasomatic rocks in geothermal or mineral industries.

The available IUGS scheme is certainly suitable for the classification of fresh rocks and was used as a reference for the evaluation of the new scheme. Independent evaluation of the IgRoClaMSys_ilr scheme from data not used for proposing it fully confirmed its good functioning. The application studies documented in this work clearly suggest that the new scheme should be used for the nomenclature of altered igneous rocks. An innovative application was also suggested for inferring igneous provenance of siliciclastic sediments and sedimentary rocks.

\section{Acknowledgements}

This work constitutes a part of the second author's (MARG) doctoral thesis in preparation under the guidance of the first author (SPV). This work was funded by DGAPA-PAPIIT grant IN100816 and IER-UNAM internal grant to the first author. We are grateful to two reviewers (Vinod K. Singh and Rajesh K. Srivastava) and the editors (Fareeduddin and Bokyun Ko) for appreciation of our work and comments to help us improve our presentation. Alfredo Quiroz-Ruiz is thanked for the computing facility and server maintenance. 


\section{References}

Abu-Hamatteh, J.H.S., 2002, Geochemistry and tectonic framework of Proterozoic mafic metavolcanics of Aravalli-Delhi Orogen, NW India: Chemie der Erde, v. 62, pp. 123-144.

Agrawal, S., 1999, Geochemical discrimination diagrams: a simple way of replacing eye-fitted boundaries with probability based classifier surfaces: Journal of the Geological Society of India, v. 54, no. 4, pp. 335346

Aitchison, J., 1984, Statistical analysis of geochemical compositions: Mathematical Geology, v. 16, no. 6, pp. 531-564.

Aitchison, J., 1986, The Statistical Analysis of Compositional Data: Chapman and Hall, London, $83 \mathrm{p}$.

Aitchison, J., 1999, Logratios and natural laws in compositional data analysis: Mathematical Geology, v. 31, no. 5, pp. 563-580.

Barnett, V., and Lewis, T., 1994, Outliers in Statistical Data ( ${ }^{\text {rd }}$ edition): John Wiley \& Sons, Chichester, $584 \mathrm{p}$.

Bateman, R., Costa, S., Swe, T., and Lambert, D., 2001, Archaean mafic magmatism in the Kalgoorlie area of the Yilgarn Craton, western Australia: a geochemical and Nd isotopic study of the petrogenetic and tectonic evolution of a greenstone belt: Precambrian Research, v. 108, pp. $75-112$.

Binard, N., Maury, R.C., Guille, G., Talandier, J., Gillot, P.Y., and Cotten, J., 1993, Mehetia island, South Pacific: geology and petrology of the emerged part of the Society hot spot: Journal of Volcanology and Geothermal Research, v. 55, pp. 239-260.

Butler, J.C., 1979, Trends in ternary petrologic variation diagrams - fact or fantasy?: American Mineralogist, v. 64, no. 9-10, pp. 1115-1121.

Butler, J.C., 1982, The closure problem as reflected in discriminant function analysis: Chemical Geology, v. 37, pp. 367-375.

Chayes, F., 1960, On correlation between variables of constant sum: Journal of Geophysical Research, v. 65, no. 12, pp. 4185-4193.

Chayes, F., 1978, Ratio Correlation: A Manual for Students of Petrology and Geochemistry: The University of Chicago Press, Chicago, 108 p.

Di Piazza, A., Rizzo, A.L., Barberi, F., Carapezza, M.L., De Astis, G., Romano, C., and Sortino, F., 2015, Geochemistry of the mantle source and magma feeding system beneath Turrialba volcano, Costa Rica: Lithos, v. 232, pp. 319-335.

Egozcue, J.J., Pawlowsky-Glahn, V., Mateu-Figueras, G., and BarcelóVidal, C., 2003, Isometric logratio transformations for compositional data analysis: Mathematical Geology, v. 35, no. 3, pp. 279-300.

Floyd, P.A., and Winchester, J.A., 1975, Magma type and tectonic setting discrimination using immobile elements: Earth and Planetary Science Letters, v. 27, no. 2, pp. 211-218.

Floyd, P.A., and Winchester, J.A., 1978, Identification and discrimination of altered and meta-morphosed volcanic rocks using immobile elements: Chemical Geology, v. 21, no. 3-4, pp. 291-306.

Garcia, M.O., Weis, D., Jicha, B.R., Ito, G., and Hanano, D., 2016, Petrology and geochronology of lavas from Ka'ula Volcano: implications for rejuvenated volcanism of the Hawaiian mantle plume: Geochimica et Cosmochimica Acta, v. 185, pp. 278-301.

Grajales-Nishimura, J.M., Centeno-García, E., Keppie, J.D., and Dostal, J., 1999, Geochemistry of Paleozoic basalts from the Juchatengo complex of southern México: tectonic implications: Journal of South American Earth Sciences, v. 12, pp. 537-544.

Ishiga, H., Nakamura, T., Sampei, Y., Tokuoka, T., and Takayasu, K., 2000, Geochemical record of the Holocene Jomon transgression and human activity in coastal lagoon sediments of the San'in district SW Japan: Global and Planetary Change, v. 25, pp. 223-237.

Janser, B.W., 1992,The geology, geochemistry, and metallogeny of the Star lake area, northern Saskatchewan: Master's Thesis, University of Sasketchawan, Saskatoon.

Janser, B.W., 1994, The Star lake pluton, La Ronge domain, northern Saskatchewan: petrogenesis of a Proterozoic island-arc pluton: Precam- brian Research, v. 70, pp. 145-164.

Le Bas, M.J., 2000, IUGS reclassification of the high-Mg and picritic volcanic rocks: Journal of Petrology, v. 41, no. 10, pp. 1467-1470.

Le Bas, M.J., Le Maitre, R.W., Streckeisen, A., and Zanettin, B., 1986, A chemical classification of volcanic rocks based on the total alkali-silica diagram: Journal of Petrology, v. 27, no. 3, pp. 745-750.

Le Maitre, R.W., Streckeisen, A., Zanettin, B., Le Bas, M.J., Bonin, B., Bateman, P., Bellieni, G., Dudek, A., Schmid, R., Sorensen, H., and Woolley, A.R., 2002, Igneous Rocks: A Classification and Glossary of Terms: Recommendations of the International Union of Geological Sciences Subcommission of the Systematics of Igneous Rocks ( $2^{\text {nd }}$ edition): Cambridge University Press, Cambridge, $236 \mathrm{p}$.

Middlemost, E.A.K., 1994, Naming materials in the magma/igneous rock system: Earth Science Reviews, v. 37, no. 3-4, pp. 215-224.

Mora, J.C., Macías, J.L., García-Palomo, A., Arce, J.L., Espíndola, J.M., Manetti, P., Vaselli, O., and Sánchez, J.M., 2004, Petrology and geochemistry of the Tacaná Volcanic complex, Mexico-Guatemala: evidence for the last $40000 \mathrm{yr}$ of activity: Geofísica Internacional, v. 43, no. 3, pp. 331-359.

Odoma, A.N., Obaje, N.G., Omada, J.I., Idakwo, S.O., and Erbacher, J., 2015, Mineralogical, chemical composition and distribution of rare earth elements in clay-rich sediments from southeastern Nigeria: Journal of African Earth Sciences, v. 102, pp. 50-60.

Peltonen, P., Kontinen, A., and Huhma, H., 1996, Petrology and geochemistry of metabasalts from the $1.95 \mathrm{Ga}$ Jormua ophiolite, northeastern Finland: Journal of Petrology, v. 37, no. 6, pp. 1359-1383.

Pinto, L., Hérail, G., Moine, B., Fontan, F., Charrier, R., and Dupré, B., 2004, Using geochemistry to establish the igneous provenances of the Neogene continental sedimentary rocks in the Central Depression and Atliplano, Central Andes: Sedimentary Geology, v. 166, pp. 157-183.

Rencher, A.C., 2002, Methods of Multivariate Analysis ( $2^{\text {nd }}$ edition): Wiley-Interscience, New York, $708 \mathrm{p}$.

Shaw, J.E., Baker, J.A., Menzies, M.A., Thirlwall, M.F., and Ibrahim, K.M., 2003, Petrogenesis of the largest intraplate volcanic field on the Arabian Plate (Jordan): a mixed lithosphere-asthenosphere source activated by lithospheric extension: Journal of Petrology, v. 44, no. 9, pp. 1657-1679.

Streckeisen, A., 1976, To each plutonic rock its proper name: Earth Science Reviews, v. 12, pp. 1-33.

Streckeisen, A.L., 1967, Classification and nomenclature of igneous rocks: Neues Jahrbuch für Mineralogie-Abhandlungen, v. 107, no. 2-3, pp. 144-240.

Verma, S.P., 2012, Geochemometrics: Revista Mexicana de Ciencias Geológicas, v. 29, no. 1, pp. 276-298.

Verma, S.P., 2015, Monte Carlo comparison of conventional ternary diagrams with new log-ratio bivariate diagrams and an example of tectonic discrimination: Geochemical Journal, v. 49, no. 4, pp. 393-412.

Verma, S.P., and Agrawal, S., 2011, New tectonic discrimination diagrams for basic and ultrabasic volcanic rocks through log-transformed ratios of high field strength elements and implications for petrogenetic processes: Revista Mexicana de Ciencias Geológicas, v. 28, no. 1, pp. 24-44.

Verma, S.P., and Rivera-Gómez, M.A., 2013, Computer programs for the classification and nomenclature of igneous rocks: Episodes, v. 36, no. 2, pp. 115-124.

Verma, S.P., and Verma, S.K., 2013, First 15 probability-based multidimensional discrimination diagrams for intermediate magmas and their robustness against post-emplacement compositional changes and petrogenetic processes: Turkish Journal of Earth Sciences, v. 22, no. 6, pp. 931-995.

Verma, S.P., Rodríguez-Rios, R., and González-Ramírez, R., 2010, Statistical evaluation of classification diagrams for altered igneous rocks: Turkish Journal of Earth Sciences, v. 19, pp. 239-265.

Verma, S.P., Rivera-Gómez, M.A., Díaz-González, L., and Quiroz-Ruiz, A., 2016a, Log-ratio transformed major-element based multidimensional classification for altered High-Mg igneous rocks: Geochemistry, Geophysics, Geosystems, v. 17, pp. 1-14. 
Verma, S.P., Díaz-González, L., Pérez-Garza, J.A., and Rosales-Rivera, M., 2016b, Quality control in geochemistry from a comparison of four central tendency and five dispersion estimators and example of a geochemical reference material: Arabian Journal of Geosciences v. 9, Art. 740, pp. 1-14.

Verma, S.P., Rivera-Gómez, M.A., Díaz-González, L., Pandarinath, K., Amezcua-Valdez, A., Rosales-Rivera, M.A., Verma, S.K., Quiroz-Ruiz, A., and Armstrong-Altrin, J.A., 2017a, Multidimensional classification of magma types for altered igneous rocks and application to their tectonomagmatic discrimination and igneous provenance of siliciclastic sediments: Lithos, v. 278-281, pp. 321-330.

Verma, S.P., Díaz-González, L., Pérez-Garza, J.A., and Rosales-Rivera,
M., 2017b, Erratum to: Quality control in geochemistry from a comparison of four central tendency and five dispersion estimators and example of a geochemical reference material: Arabian Journal of Geosciences, v. 10, Art. 24, pp. 1-3.

Wilks, S.S., 1963, Multivariate statistical outliers: Sankhya, v. 25, pp. 407-426.

Winchester, J.A., and Floyd, P.A., 1976, Geochemical magma type discrimination: application to altered and metamorphosed basic igneous rocks: Earth and Planetary Science Letters, v. 28, no. 3, pp. 459-469.

Winchester, J.A., and Floyd, P.A., 1977, Geochemical discrimination of different magma series and their differentiation products using immobile elements: Chemical Geology, v. 20, pp. 325-343.

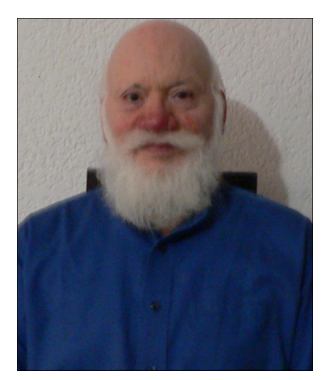

Surendra P. Verma is a Senior Scientist at the Universidad Nacional Autónoma de México. He received $\mathrm{PhD}$ degree from the Indian Institute of Science, Bangalore, India in 1971. He has published more than 260 peerreviewed papers and two books, with around 5000 external citations and the h-index of over 40 (google scholar). His scientific interest includes research and teaching in Igneous and Sedimentary Rock Geochemistry and Geochemometrics, Isotope Geology, Monte Carlo Simulations, Geothermal Energy, and Univariate, Bivariate, and Multivariate Statistics. He has been a visiting scientist in Germany, India, Italy, Spain, Mexico, and the U.S.A; he has supervised 32 thesis at the undergraduate and 15 at the graduate (Master's and Doctor's) levels; he has delivered about 115 invited talks in different institutions and 230 oral talks in scientific meetings; and he has taught 75 courses at undergraduate, graduate and professional levels.

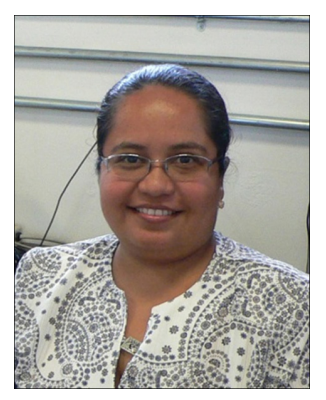

M. Abdelaly Rivera-Gómez has finalized her Doctorate studies in Engineering (Geothermal Energy) at the Institute of Renewable Energy of the National Autonomous University of Mexico (Temixco, Morelos). She holds a Bachelor degree in Informatics and a Master's in Renewable Energy. She possesses expertise in programming in different languages, including Java and ZK Framework; she has written and published several programs such as IgRoCS and TecD for their use in Geosciences; and she is one of the persons who maintain the website tlaloc.ier.unam.mx. 